\title{
A trip through Oceanic Lithosphere: 2019 international work- shop and field trip of IGCP 649 in Muscat, Oman
}

\author{
${ }^{1}$ CARMA, Key Laboratory of Deep-Earth Dynamics of MLR, Institute of Geology, Chinese Academy of Geological Sciences, Beijing \\ 100037, China; *Corresponding author,E-mail: yangjsui@163.com \\ ${ }^{2}$ School of Earth Sciences and Engineering, Nanjing University, Nanjing 210023, China \\ ${ }^{3}$ Earth Science Research Centre, Sultan Qaboos University, Al-Khoud, 123, Muscat, Oman \\ ${ }^{4}$ Leibniz Universität Hannover, Institut für Mineralogie, Callinstr. 3, Hannover D-30167, Germany
}

(Received: January 10, 2020; Revised accepted: May 17, 2020)

https://doi.org/10.18814/epiiugs/2020/020067

\section{International Workshop of IGCP 649}

The IGCP-649 project "Diamonds and Recycled Mantle" has held her Fifth workshop successfully on November, 12-22, 2019 in Muscat, Sultanate of Oman. Prof. Jingsui Yang (CARMA, Institute of Geology of CAGS, China) and Prof. Sobhi Nasir (UNESCO Chair for Ophiolite Studies and Director-Earth Sciences Research Centre, Sul$\tan$ Qaboos University) led the workshop. The workshop consisted of a two-day conference hosted at Sultan Qaboos University, Muscat, Oman (Fig. 1) and an eight-day post-conference field trip investigating the ophiolite and chromitites in the Fanja-Al-Khodh-Somarah, Ibra and Maqsad area, southwest of Muscat, Wadi Al Jizzi volcanics, copper and chromite mines in Sohar area, northern Oman, and chromitites, carbonatite and ultramafic lamprophyre in eastern Oman ophiolite (Fig. 2). Attendees have visited the world famous Semail ophiolite (including crustal sequence, mantle sequence and the "Moho" boundary), chromite deposits, as well as the metamorphic sole (blueschists, eclogites, marble and pelitic schist in the Sifah area) in Oman.

Near 100 scientists from Oman, China, America, Germany, Austra- lia, New Caledonia, Russia, Egypt, Iran and Morocco attended the workshop held on 13-14 November, 2019 in Sultan Qaboos University. They have presented their excellent work in terms of different scientific issues, especially on the new theories about the formation processes of ophiolite and related chromitites. Prof. Sobhi Nasir made welcoming speech to all the participants and introduced the geology setting of Oman. Prof. Jingsui Yang, chief director of IGCP-649 project, introduced the general situation and research progress of the project. In recent years, the project team has successively found diamonds and other ultrahigh-pressure (UHP) minerals in ophiolitic mantle peridotites as well as podiform chromitites from different orogenic belts, indicating that they may be ubiquitous in oceanic mantle peridotites (Yang et al., 2015b; Dilek and Yang, 2018). The diamonds found in ophiolites are different from those from the kimberlites and UHP metamorphic rocks in terms of their inclusions and light carbon isotope compositions (Lian et al., 2018). Dr. Cong Zhang from Institute of Geology, Chinese Academy of Geological sciences, and presided over the meeting and made a scientific report. Dr. Fahui Xiong from Institute of Geology, reported the new confirmed minerals by International Mineralogical Association Commission on New Minerals and Min-

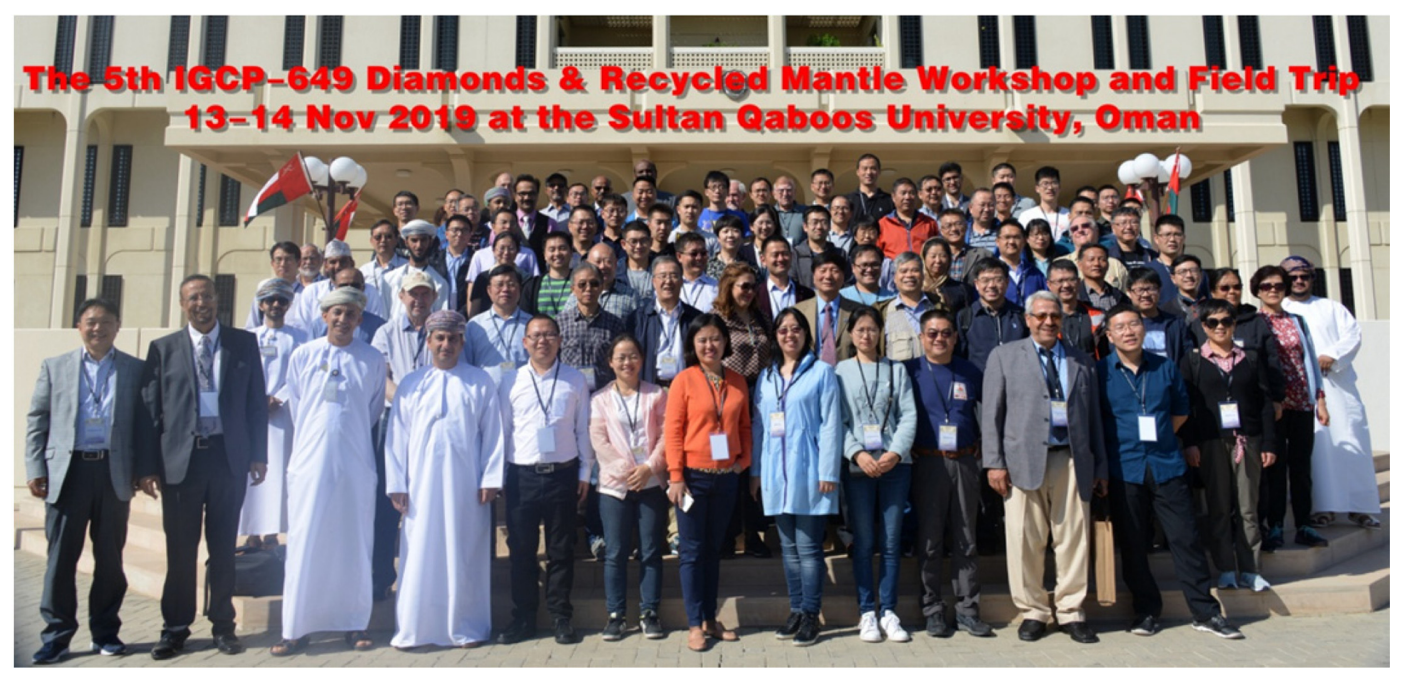

Figure 1. Workshop attendees at the $5^{\text {th }}$ International Ophiolite Workshop of IGCP-649 in Muscat, Sultanate of Oman. 


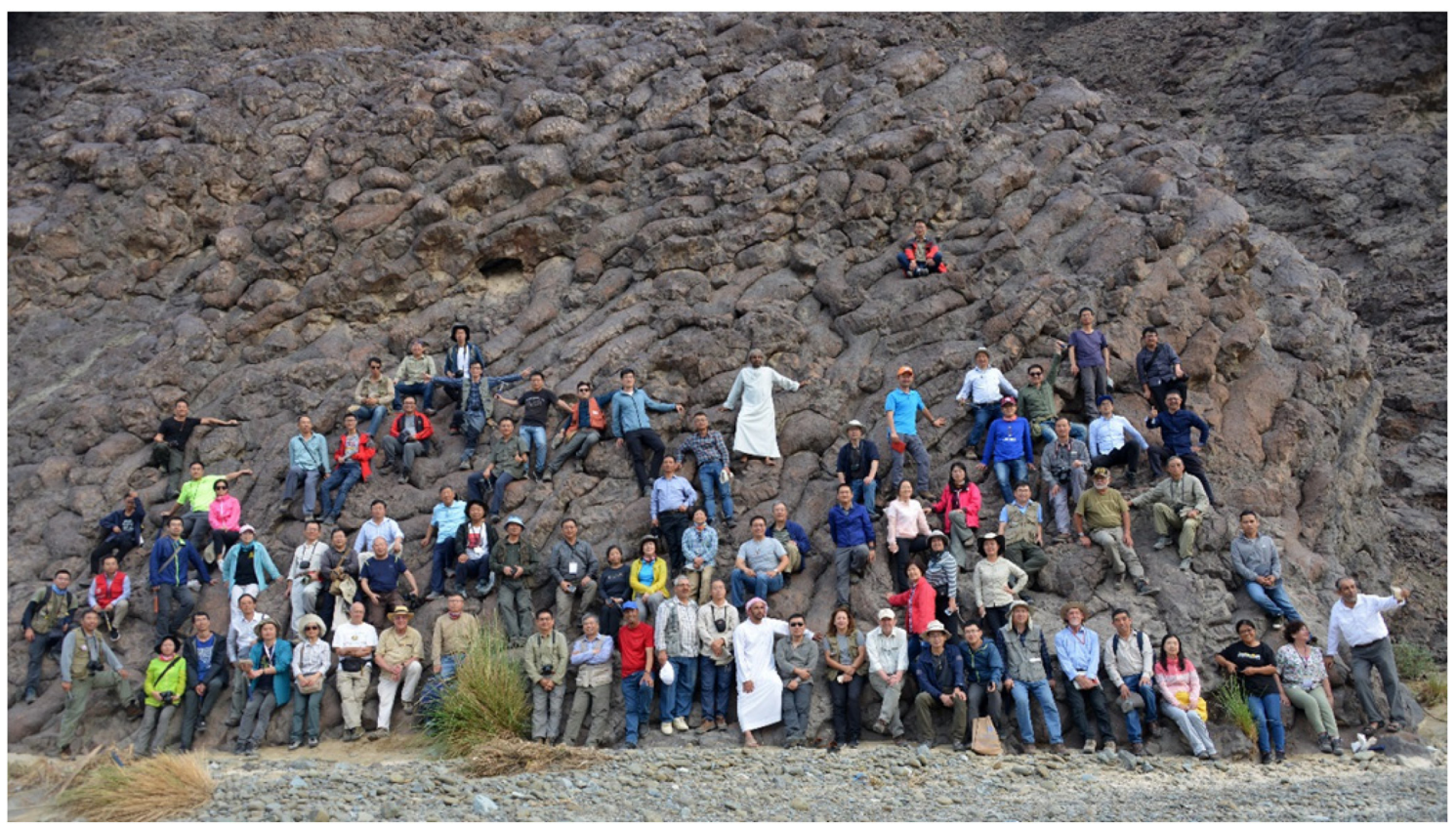

Figure 2. Workshop attendees at "Geotimes" outcrop which is world's top site for pillow basalts.

eral Names (IMA-CNMMN): Jingsuiite (IMA 2018-117b), Zhiqinite (IMA 2019-076) and Badengzhuite (IMA 2019-077) (https://doi.org/ 10.1180/mgm.2019.73). In all, the workshop provided an excellent opportunity for geoscience communication.

\section{Field Trip of the 2019 International Workshop of IGCP 649}

The Sultanate of Oman is situated close to the north-eastern margin of the Arabian Plate. The Arabian Plate is bounded to the north-east by the Bitlis-Zagros collision zone and the Makran subduction zone, to the north-west and south-east by the Levant and Owen strike-slip faults, respectively, and to the south-west and south by the active spreading axes of the Red Sea and Gulf of Aden rifts. Convergence along the North Oman continental margin is accommodated by subduction of the Gulf of Oman oceanic lithosphere below the Makran accretionary prism and Eurasian continental lithosphere. The northern Oman Mountains extend for $700 \mathrm{~km}$ from the Musandam Peninsula in the north to the Batain coast in the south-east (LeMétour et al., 1990).

The Semail ophiolite Nappe represents a slice of oceanic lithosphere formed above a northward-dipping subduction zone in a marginal basin tectonic setting (Fig. 3). The Oman Neo-Tethys have formed in the early Triassic by the rifting off and migration of small continents (e.g., Iran, Tibet, Afghanistan) northward from the remainder of Gondwana. This movement stopped in the Late Campanian (70 Ma) when the buoyant crust of the Arabian continental margin could not be pushed deeper into the dense mantle. As the American plate moved away from Africa, the Atlantic Ocean began to open, causing Africa to reverse its direction of motion and move northward. As a result, the Tethys Ocean was consumed, pushing the ophiolite, above the shallow marine limestone of the Hajar Super Group. The ophiolitic nappe was detached from a Tethyan oceanic ridge at the initiation of closure of the Neo-
Tethys between 96.5 and 95.5 Ma, along-strike the Semail ophiolite (Tilton et al., 1981; Hacker and Mosenfelder, 1996). Emplacement onto the Arabian plate took place at around $78 \mathrm{Ma}$ (Nicolas et al., 2000). Most structural and tectonic models proposed for the emplacement of the ophiolite have involved the NE-directed subduction away from the passive continental margin of the Arabian plate (e.g., Glennie et al., 1974; Lippard et al., 1986; Goffé et al., 1988; Le Métour et al., 1990; Searle et al., 1994). The thickness of the detached oceanic crust reached 15 to $20 \mathrm{~km}$.

The classic ophiolite sequence is well exposed at the Semail ophiolite. Under the headship of Prof. Sobhi Nasir and Prof. Juergen Koepke from the Leibniz University Hannover, the attendees have observed the complete oceanic crust-mantle section from residual peridotite, layered gabbro, sheeted dyke complex and effusive basaltic layer and sea sediments. This entire sequence at Semail is $12 \mathrm{~km}$ thick. The detailed field route is as below:

Stop 1 - Chromite mines and Maqsad Massif (Fig. 4): Chromitites in the Moho Transition Zone at Maqsad form stratiform and dyke-like bodies a few meters thick. Over 20 pods have been recognized in the 400-m thick MTZ overlying the Maqsad diaper. With a few exceptions, all chromite deposits are located in the lower part of the MTZ close to the transition from MTZ dunites to mantle harzburgites in a horizon of flat harzburgite/dunite interlayering. Chromitite deposits are dominantly concordant lenses of a few meters thickness. Chromitites in the dunitic Moho Transition Zone of the Oman ophiolite have compositions typical of those formed from a basaltic melt, and the standard interpretation of their origin has been their formation in melt channels in the mantle created by the migration of basaltic melts.

Stop 2 - Maqsad mantle diapir (Sumail block) at Mahram: Maqsad mantle diaper islocated under the segment center of the Oman paleoridge axis on which has been superimposed an area of mantle upwelling. This is indicated by steeply dipping lineations (up to $70^{\circ}$ ) mapped in the mantle harzburgites and is one of a number of zones of mantle 


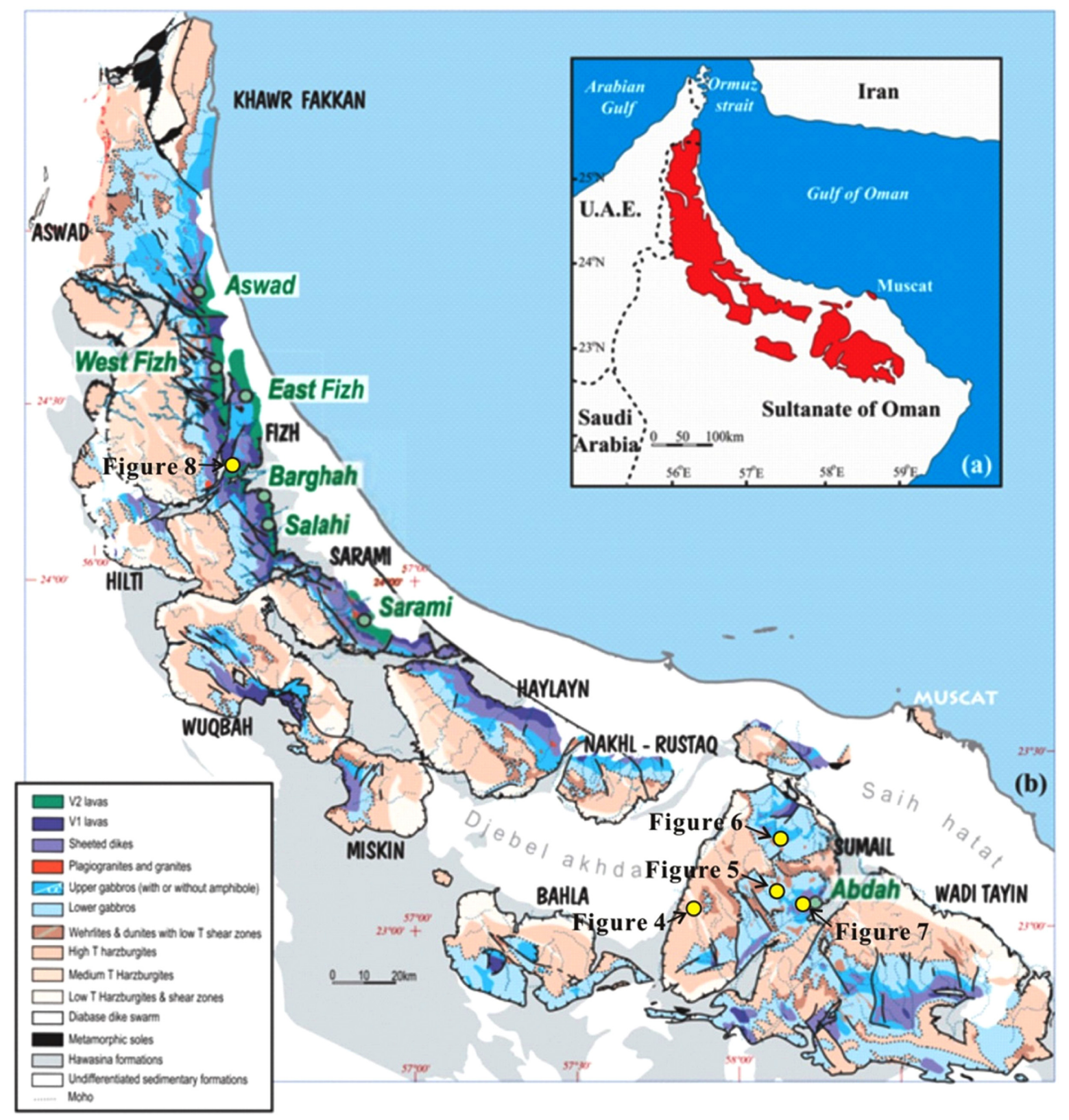

Figure 3. (a) The Oman ophiolites (red area). (b) Map of the Oman ophiolite structures (Godard et al., 2003).

upwelling or "mantle diapirs" which have been mapped in the mantle section of the Oman ophiolite (Nicolas and Boudier, 2000). The paleospreading axis is assumed to run south-east to north-west down the center of the massif. This section of mantle is assumed to have had a lot of melt passing through it as part of the diapir. The Maqsad diapir is characterized by a thick MTZ (Moho Transition Zone), documenting the exceptional high magma production rate under segment centers. The outcrop is $30-100 \mathrm{~m}$ below the MOHO. Harzburgite is the primary rock type, with areas of concentrated plagioclase and clinopyroxene. The fabric has been almost completely destroyed by melt passing through the section.

Stop 3 - Deep gabbro sills below the Moho (Fig. 5): The MTZ of the Oman ophiolite commonly includes a number of gabbros sills surrounded by dunites. The gabbros sills have millimeter-scale to tens of centimeter-scale modal layering that closely resembles layering in lower crustal gabbros of the ophiolite. These layered gabbros with wehrlite intrusions are thought to be in the transition zone below the MOHO. The petrological and geochemical observations on the gabbro sills indicate that they formed from small, open-system melt-filled lenses within the MTZ. Modal layering could develop through the expulsion cycles, probably via in situ crystallization at the margins of melt lenses.

Stop 4 - Field relations between the crustal and mantle rocks (Fig. 6): harzburgite, gabbro and wehrlite are the primary rock type, with areas of concentrated plagioclase and clinopyroxene. At this stop, the attendees can actually put their fingers on the "Moho", based on the field relations between the crustal and mantle rocks exposed in this stop. The layered gabbros with wehrlite intrusions are thought to be in the transition zone below the MOHO. The layered gabbros strike 


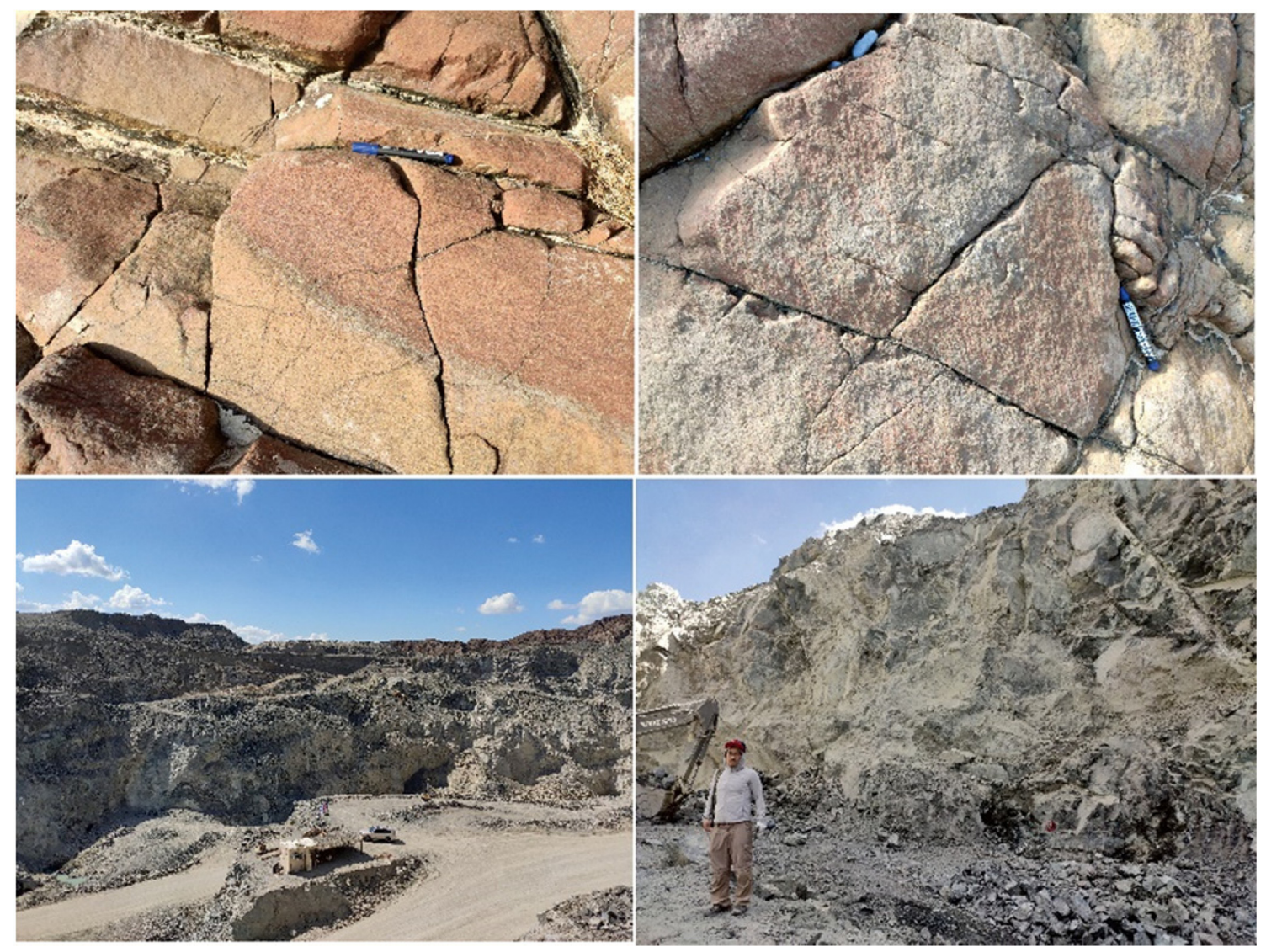

Figure 4. Mantle peridotite and chromite mine under Exploitation in the mantle peridotite.

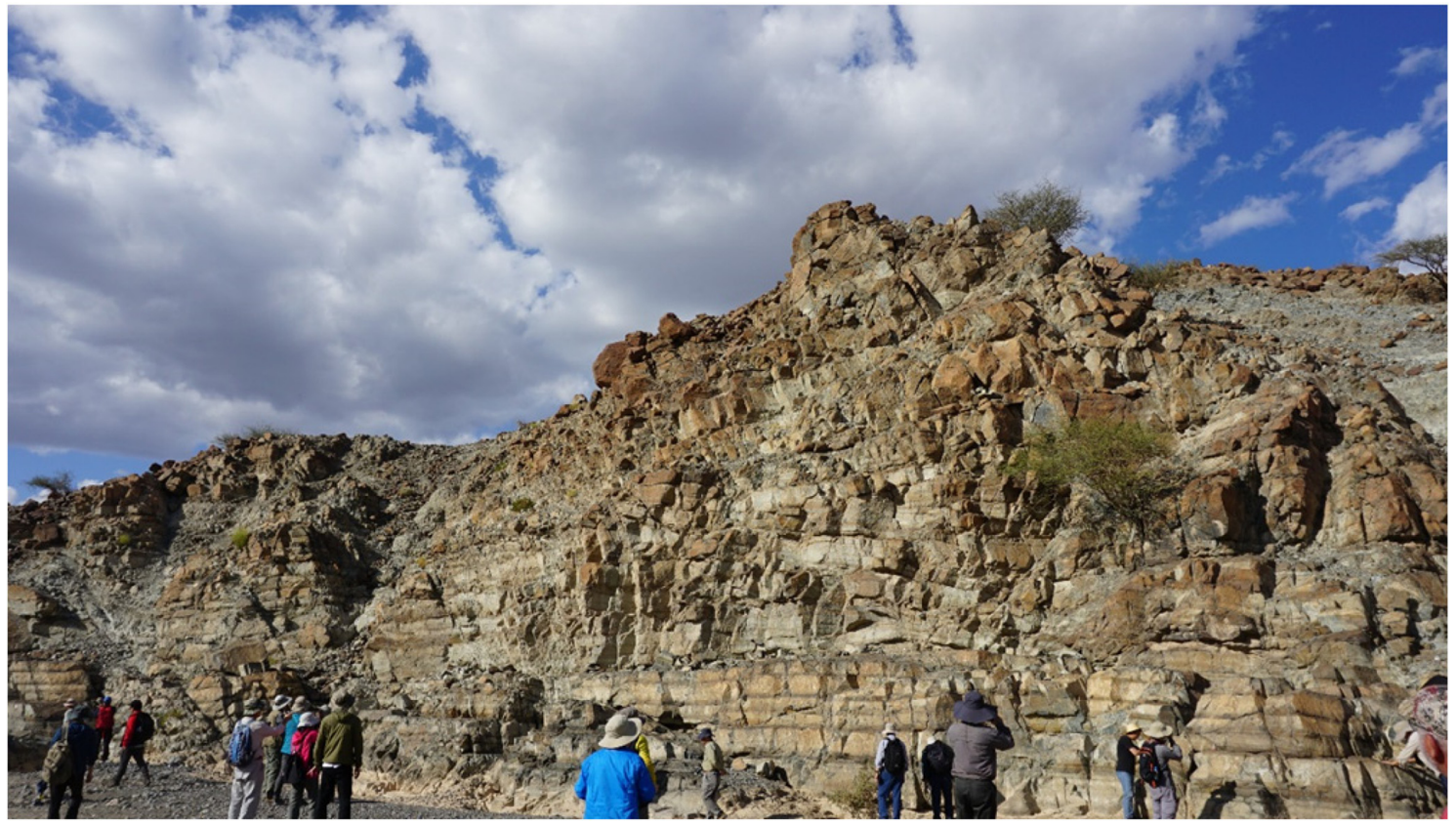

Figure 5. Gabbro sills below the Moho.

approximately east-west and dip to the south. Some of the gabbros are pegmatitic.

Stop 5 - Sheeted dykes of Somerah (Fig. 7): The dikes at this stop typically have a single chilled margin. They show obvious chilled margins and the coarser grained dike centers. It was observations of this type which led to the modern understanding of oceanic spreading centers at mid-ocean ridges.

Stop 6 - The plagiogranite near Somerah: Plagiogranites in oceanic 


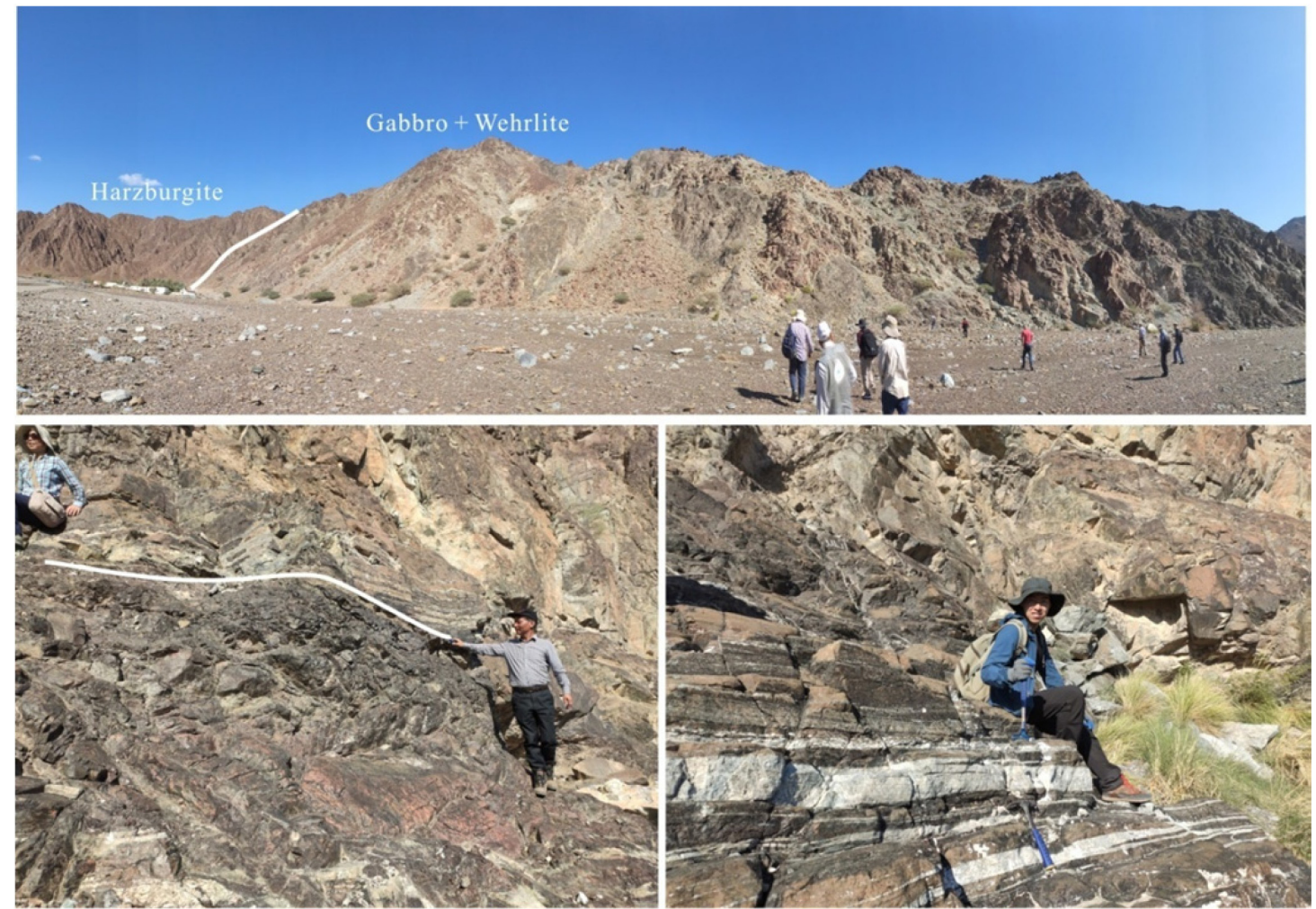

Figure 6. МОНО Transition zone.
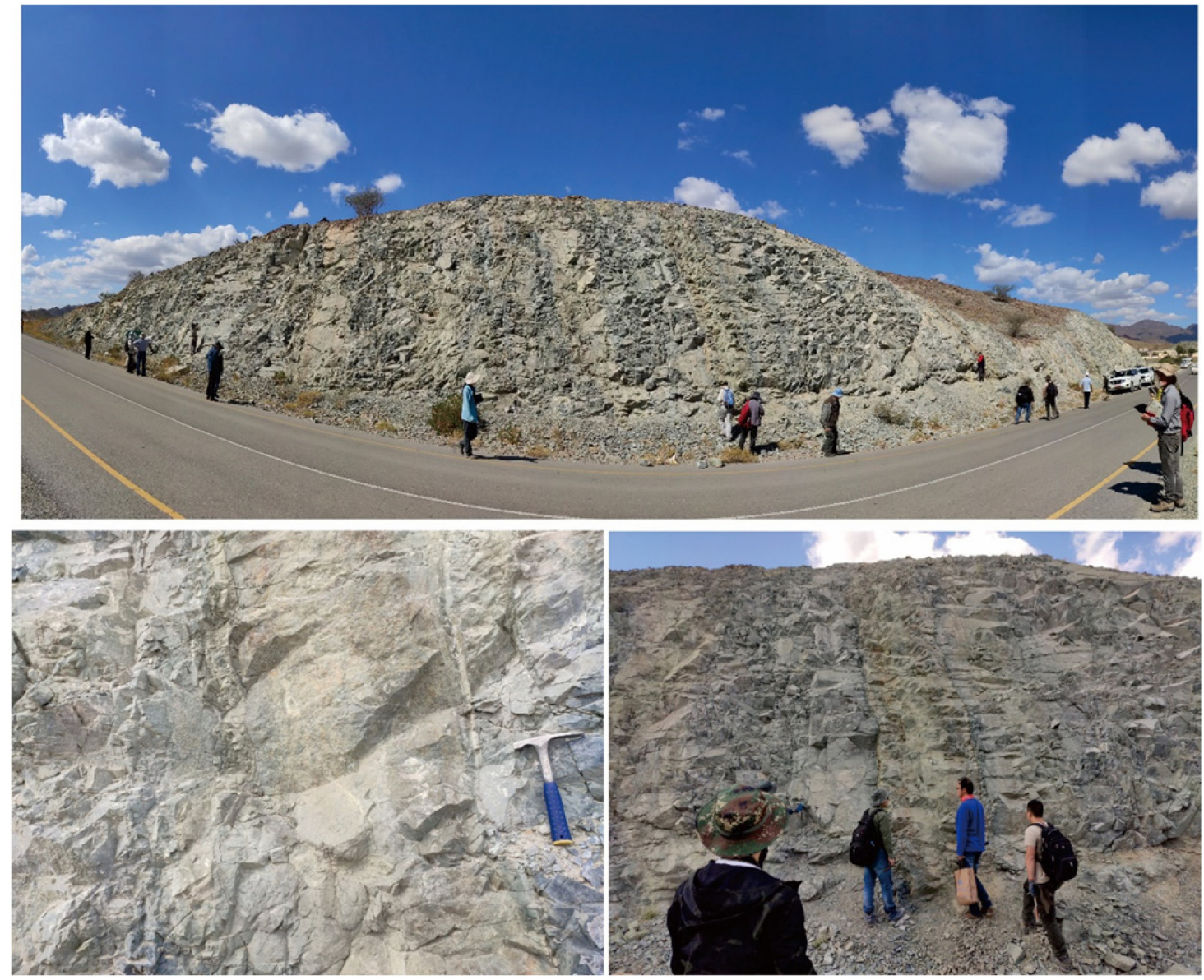

Figure 7. Sheeted dykes of Somerah. 
crust include tonalites, trondhjemites and granodiorites. Late gabbroplagiogranites intrusive complex form rounded intrusions, which are normally emplaced into the sheeted dyke unit and/or the pillow lavas of the ophiolite. These plagiogranites formed from a mafic magma by the re-melting of previously depleted mantle harzburgite followed by fractional crystallisation.

Stop 7 - Somerah layered gabbro: The outcrop of layered gabbro at Somerah is World's top site for layered gabbro. The layering is pronounced by differences in modal proportions and is therefore called modal layering. The olivine appears dark in the rock, leading to the observed color variations depending on the olivine content. Each layer covers an olivine-rich base and an olivine-poor top, with gradationally decreasing olivine content up layer. The layer thickness varies between 40 and $80 \mathrm{~cm}$.

Stop 8 - Frozen axial melt lenses (AMLs) -varitextured gabbro: The presence of axial melt lenses was discovered at fast-spreading mid-ocean ridges in the late 90s. This outcrop presents a whole suite of different lithologies and complex cutting relationships: vari-textured gabbro with relics of primitive poikilitic clinopyroxene is cutted by basaltic dykes. These gabbros are interpreted as a frozen (fossilized) filling of the AML, which crystallized in-situ. The patchy vari-textured gabbros containing domains of primitive poikilitic clinopyroxene and evolved granular networks represent the record of in-situ crystallization.

Stop 9 - Listwanite: Listwanites are the hydrothermal alteration products of mafic and ultramafic rocks composed of quartz, carbonate minerals (calcite, dolomite, magnesite and ankerite), and/or fuchsite (a Cr-mica) with sulfides (pyrite, chalcopyrite and tetrahedrite). Simply, listwanites are fully carbonated peridotites, in which all Mg-silicates have been converted to $\mathrm{Mg}$-carbonates and quartz.

Stop 10 - Dunite channels, alteration and faulting: The peridotite of Fanja area includes many dunite channels. Most of the dunites are highly altered to serpentine. Magnesioferrite and $\mathrm{Ni}-\mathrm{Fe}$ alloys are common product. This stop shows faulting of the mantle rocks due to seismic activity in the mantle. Several late stage melt channels and dykes are common.

Stop 11 - The metamorphic sole-contact with the mantle: The base of the ophiolite nappe is sporadically but widely metamorphosed and called "metamorphic sole". The metamorphic sole was formed when the hot ophiolite nappe obducted onto the oceanic sediments and effusive rocks, and gave them necessary heat and obtained fluids expelled through dehydration reactions. At the contact with the Mantle rocks, the upper unit is made of coarse-grained dark green amphibolite, passing down-section to fine-grained amphibolite, with intercalations of greygreen metaquartzit. The lower unit is composed mostly of greenschistfacies white micaceous quartzite associated with grey-green micaschist and minor banded calcic gneisss. The metasediments are affected by polyphase deformation.

Stop 12 - Seifa Metamorphic rocks: Metabasite, epidote amphibolites and glaucophane schist: This outcrop contains interlayered metapelites, quartz mica schists and metabasites. In this stop you can see different types of amphibolite schist, gneiss as well as metasediments which are metamorphosed under high pressure and low to medium pressure conditions

Stop 13 - As Sifah eclogites: The quartz + phengite \pm garnet calcschists enclosing the large eclogite boudin and the widespread NEvergent asymmetric folds in massive metabasic eclogite. Crinoid ossi- cles have been preserved in these schists above the eclogite bouding. NE-directed C-S fabrics indicate down-to-NE motion, also called an extensional crenulation cleavage. In reality these fabrics indicate SWdirected exhumation of the footwall beneath a static hanging-wall during expulsion from the NE-dipping suduction zone (Searle et al., 2004; Agard et al., 2010). The late-stage NW-SE aligned quartz-haematite veins cutting across the schistosity. Coarse-grained eclogite facies metabasites show a prograde mineral assemblage: Garnet + clinopyroxene (chloromelanite) + lawsonite + phengite + glaucophane + rutile Eclogite facies metapelites show: Quartz + phengite + garnet + chloritoid + clinopyroxene (aegerine-jadeite) + lawsonite. Pseudomorphs of clinozoisite and white mica after lawsonite enclosed in garnets show a prograde growth zoning. Eclogite garnets contain sigmoidal inclusion trails defined by rutile and omphacite, which are continuous with the matrix fabric. This prograde mineral fabric is overgrown by coarsegrained static growth of crossite + epidote + chlorite. Later greenschist facies alteration consists of albite + chlorite + biotite and narrow rims of blue-green amphibole around crossite.

Stop 14 - Visiting Copper-Gold Mines: Mawarid Mining Company: The Sultanate of Oman is traditionally known for mining copper ores since 3000 BC. Several localities of the remaining slogs have been found in different places in the Oman Mountains, particularly in the Sohar region at al-Asil ancient mine. Other places such as Samail and Samad were also very active in mining. Ore occurs as shallow open pitable copper massive sulfide deposits that dip moderately from 0 to 20 meters below the surface to a maximum depth of about 100 meters below surface. Mines have a cut-off grade of $0.3 \%$ copper and average grades of $2-3 \%$ copper. To date, the mining operations have produced a combined total of over 2.5 million metric tons of ore at an average stripping ratio of 4.6 since inception.

Stop 15 - Northern chromitites area: Most chromitite deposits in northern Oman are located at various depth in the harzburgitic mantle section. They are associated with several tens of kilometres of long shear zones of mylonitic peridotites distributed mainly in the Fizh and Hilti mantle sections. In the Fizh massif, the mantle shear bands rotating at depth are inferred to connect with the flat-lying metamorphic sole.

Stop 16 - Geotime pillow lava, Wadi Jizi (Fig. 8): The initial division of the extrusive sequence into five units (Lippard et al., 1986) has been grouped into three sequences in geological maps (Ernewin et al., 1988). The Geotimes unit (or V1) directly overlies the sheeted dike complex with gradational contacts. It is composed of 750-1500 m of redish basaltic toandesitic lavas. The majority are non vesicular and aphyric. Geotimes lavas have trace elementcompositions similar to N-MORB. The classical "Geotimes" outcrop is world's top site for pillow basalts. We have seen that the structure of the lava emplacement corresponds more to tubes, than to pillows. And observed crosscutting dikes which fed the uppermost extrusive units.

Stop 17 - Carbonatite: Four occurrences of carbonatite dikes and plugs associated with ultramafic and alkaline igneous rocks have been discovered along Wadi Sal area within the Batain nappes, eastern Oman. The carbonatites display a wide petrographic and geochemical spectrum and range in composition from magnesiocarbonatites to ferruginous calciocarbonatites. The carbonatites are interpreted as primary magnesiocarbonatite contaminated by mantle-derived material and isotopically re-equilibrated with low-temperature crustal fluids. The close spatial association of carbonatite and ultramafic igneous rocks 

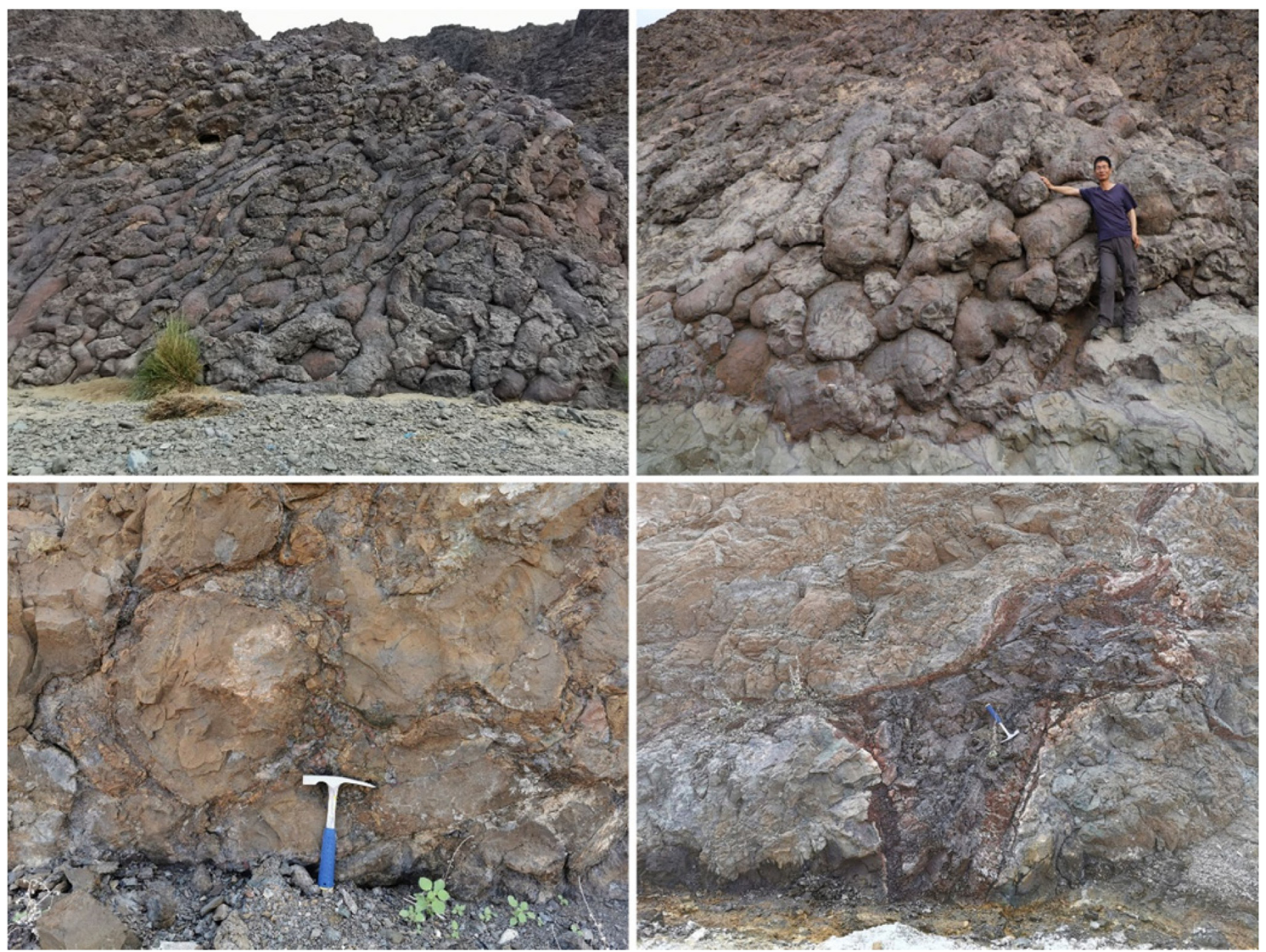

Figure 8. Geotime pillow lava, Wadi Jizi.

(aillikite and damtjernite) along with geological, petrographical and geochemical data indicates that these rocks are of intra-oceanic origin.

Stop 18 - Ultramafic lamrophyres: The lamprophyric dyke swarms of the Bomethra area comprise macrocrystic, spinel and phlogopite bearing hybabyssall facies calcite aillikite/damtjernite with pelletal lapilli and globular segregationary textures. The main dyke extends in length up to $6 \mathrm{~km}$ and ranges in width between 1 and 30 meters.

Stop 19 - Chromitites within the Masirah melange: Several chromitite deposits have been discovered in the ophiolite of the Batain mélange, Wadi Musawa, Eastern Oman. These deposits have been extensively altered and deformed, with the host pyroxenite and dunite. The chromitites occur as separated small concordant or lenticular pods outcrops (3-10 $\mathrm{m}$ in thickness). The chromitites show disseminated or massive textures. Most primary silicate minerals are converted to secondary chlorite, serpentinite and pargasite. Olivine and clinopyroxene occurs as inclusions in the spinel grains. Discriminant geochemical diagrams based on the mineral chemistry of harzburgites indicate a Mid-Ocean-Ridge origin.

\section{Summary}

IGCP-649 project "Diamonds and Recycled Mantle" (2015-2019) is aimed to carry out extensive and systematic research on the peridotites, chromitites, and related high pressure and reduced minerals such as diamond, moissanite and other unusual minerals, from different ophiolites and orogenic belts in the world, in order to understand the formation and origin of deep-mantle minerals in oceanic lithosphere, the origin of carbon for the ophiolite-hosted diamonds, the evolution of Earth's mantle and the dynamic process of ophiolite emplacement and also to provide new model for chromitite formation and exploration. Since 2015, the IGCP-649 workshops and field excursions have been held at the world well-known classic ophiolites and chromitites exposed areas, such as the North Qilian ophiolite in China (Yang et al., 2015a), the Troodos ophiolite in Cyprus (Yang et al., 2016), the Mayari-Baracoa ophiolites and chromitites in Cuba (Yang et al., 2017), the Massif du Sud ophiolite in New Caledonia (Yang and Shen, 2018), and the Semail ophiolite in Oman this year (2019). In addition to holding workshops and field excursions, the IGCP-649 project has also organized many scientific sessions on ophiolites and chromitites in world well-known international conferences, e.g., Goldschmidt Conference (2015, 2017, 2019), Annual Meeting of Geological Society of America $(2015,2017)$, the International Geological Congress (2016, 2020 now postponed), and published several special issues of the journals, such as Gondwana Research (2015), Lithosphere (2018), Earth Sciences (2019), as well as abstract volumes $(2015,2016,2017,2018,2020)$ in the journal Acta Geologica Sinica. All these scientific activities and publications provided an excellent opportunity for international geologists and earth science communications to gather and exchange their new achievements and perspectives. 


\section{Acknowledgements}

As the close year of this project, we would express our grateful to many individuals and organizations for their strong supports and helps. They are the UNESCO (United Nations Education, Scientific and Cultural Organization), IUGS (International Union of Geological Sciences) and IGCP program, Dr. Costas Constantinou of the Cyprus Geological Survey Department, Dr. Kenya Elvira Nuñez Cambra of Cuban Society of Geology, Dr. Luis J. Gomez Narbona of the Cuba Geological Survey, Prof. Yurisley Valdes Marino of the High Mining Metallurgic Institute of Moa in Cuba, Prof Jonathan Archison of the Quensland University, Prof. Dominique Cluzel of the University of New Caledonia, Dr. Rahma Ibrahim Al-Mahrooqi of Sultan Qaboos University in Oman. Dr. Cong Zhang and other CARMA members. Without their great contributions all the programs and activities would not be able to be carried out so smoothly and successfully. The IGCP 649 project was financially supported by the IGCP program under the UNESCO, IUGS and by the NSF of China (41720104009). We would express our deep appreciation to them all.

\section{References}

Agard, P., Searle, M.P., Alsop, G.I., and Dubacq, B., 2010, Crustal stacking and expulsion tectonics during continental subduction: P-T deformation constraints from Oman. Tectonics, v. 29, pp. TC5018, doi:10.1029/ 2010TC002669

Dilek, Y., and Yang, J.S., 2018, Ophiolites, diamonds, and ultrahigh-pressure minerals: New discoveries and concepts on upper mantle petrogenesis. Lithosphere, v. 10, pp. 3-13.

Ernewein, M., Pflumio, C., and Whitechurch, H., 1988, The death of an accretion zone as evidenced by the magmatic history of the Sumail ophiolite (Oman). Tectonophysics, v. 151, pp. 247-274.

Glennie, K.W., Boeuf, M.G., Hughes-Clarke, M.H.W., Moody-Stuart, M., Pilaar, W.F., and Reinhardt, B.M., 1974, Geology of the Oman Mountains. Verhandelingen Koninklijk Nederlands geologisch mijnbouwkundidg Genootschap, v. 31, pp. 423.

Godard, M., Dautria, J.M., and Perrin, M., 2003, Geochemical variability of the Oman ophiolite lavas: Relationship with spatial distribution and paleomagnetic directions. Geochemistry, Geophysics, Geosystems, v. 4, pp. 8609, doi:10.1029/2002GC000452

Goffé, B., Michard, A., Kienast, J.R., and LeMer, O., 1988, A case of obduction-related high-pressure low-temperature metamorphism in upper crustal nappes, Arabian continental margin, Oman: $\mathrm{P}-\mathrm{T}$ paths and kinematic interpretation. Tectonophysics, v. 151, pp. 363-386.

Hacker, B.R., and Mosenfelder, J.L., 1996, Metamorphism and deforma- tion along the emplacement thrust of the Samail ophiolite, Oman. Earth and Planetary Science Letters, v. 144, pp. 435-451.

LeMétour, J., Rabu, D., Tegyey, M., Bechennec, F., Beurrier, M., and Villey, M., 1990, Subduction and obduction: two stages in the Eo-Alpine tectonometamorphic evolution of the Oman mountains. In: Robertson, A.F.H., Searle, M.P., Ries, A.C. (Eds), The Geology and Tectonics of the Oman Region. Geological Society, London, Special Publication, no. 49, pp. 327-339.

Lian, D.Y., Yang, J.S., Wiedenbeck, M., Dilek, Y., Rocholl, A., and Wu, W.W., 2018, Carbon and nitrogen isotope, and mineral inclusion studies on the diamonds from the Pozanti-Karsanti chromitite, Turkey. Contributions to Mineralogy and Petrology, v. 173, pp. 72, doi:10.1007/ s00410-018-1499-5

Lippard, S.J., Shelton, A.W., and Gass, I.G., 1986, The Ophiolite of Northern Oman. Blackwell Scientific Publications, Oxford, pp. 178.

Nicolas, A., and Boudier, F., 2000, Large mantle upwellings and related variations in crustal thickness in the Oman ophiolite. Geological Society of America, Special Paper, v. 349, pp. 67-73.

Nicolas, A., Boudier, F., Ildefonse, B., and Ball, E., 2000, Accretion of Oman and United Arab Emirates ophiolite - Discussion of a new structural map. Marine Geophysical Researches, v. 21, pp. 147-179.

Searle, M.P., Warren, C.J., Waters, D.J., and Parrish, R.R., 2004, Structural evolution, metamorphism and restoration of the Arabian continental margin, Saih Hatat region, Oman Mountains. Journal of Structural Geology, v. 26, pp. 451-473.

Searle, M.P., Waters, D.J., Martin, H.N., and Rex, D.C., 1994, Structure and metamorphism of blueschist-eclogite facies rocks from the northeastern Oman Mountains. Journal of Geological Society, London, v. 151, pp. 555-576.

Tilton, G.R., Hopson, C.A., and Wright, J.E., 1981, Uranium-lead isotopic ages of the Samail ophiolite, Oman, with applications to Tethyan ocean ridge tectonics. Journal of Geophysical Research, v. 86, pp. 2763-2775.

Yang, J.S, and Shen, T.T., 2018, IGCP-649 project held 2018 international workshop and field trip in Brisbane, Australia and New Caledonia. Episodes, v. 41, pp. 1-7.

Yang, J.S., Dilek, Y., and Robinson, P.T., 2015a, Diamond and recycled mantle: a new perspective___introduction of IGCP-649 project. Acta Geologica Sinica (English Edition), v. 89, pp. 1037-1038.

Yang, J.S., Pearce, J., and Dilek, Y., 2016, Probing the Troodos ophiolite: IGCP-649 workshop and field excursion held in Agros-Cyprus. Acta Geologica Sinica (English Edition), v. 90, pp. 1041-1044.

Yang, J.S., Qiu, T., and Llanes Castro, A.I., 2017, Report on the third IGCP-649 international workshop on the Mayarí-Baracoa ophiolites and chromitites, Cuba. Acta Geologica Sinica (English Edition), v. 91, pp. 2305-2309.

Yang, J.S., Robinson, P.T., and Delik, Y., 2015b, Diamond-bearing ophiolites and their geological occurrence. Episodes, v. 38, pp. 344-364.

Yang, J.S., and Shen, T.T., 2018, IGCP-649 project held 2018 international workshop and field trip in Brisbane, Australia and New Caledonia. Episodes, v. 41, pp. 1-7. 


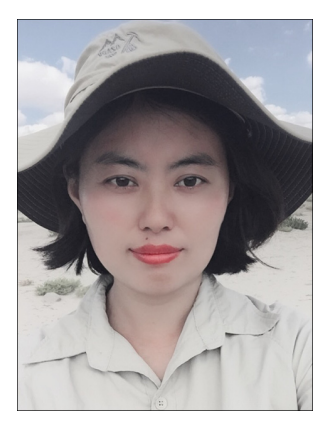

Dr. Xiaolu Niu is an associate Professor for petrology in Institute of Geology, Chinese Academy of Geological Sciences. She received her PhD at Peking University, China in 2011. Her main interest is the understanding of the origin and formation processes of igneous rocks.

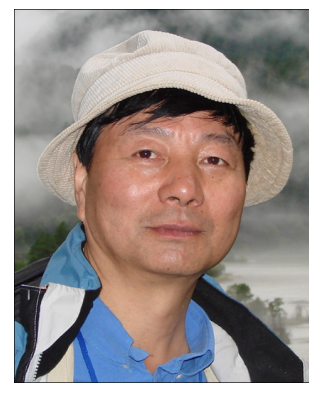

Jingsui Yang his $\mathrm{PhD}$ at Dalhousie University, Canada in 1992. He became a Professor in Institute of Geology, Chinese Academy of Geological Sciences in 1995. Now he is a professor in School of Earth Sciences and Engineering, Nanjing University, and academician of Chinese Academy of Sciences. He is the leader of the Center of Advanced Research of Mantle (CARMA) and working on ophiolites, particularly on high pressure minerals in mantle rocks, as well as on ultra-high pressure metamorphic rocks in subduction zones on the Tibetan plateau and other orogenic belts. He is the author and co-author of over 300 publications in international journals and conference proceedings. He is a Fellow of the Mineralogical Society of America (MSA) and a Fellow of the Geological Society of America (GSA).

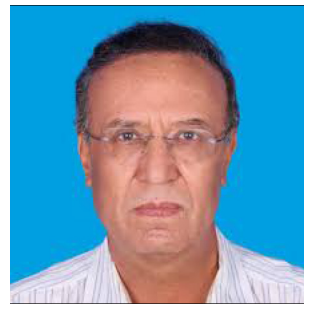

Sobhi Nasir is the Director of Earth Sciences Research Centre at the Sultan Qaboos University and the UNESCO Chair for Ophiolites Studies. He is also the Chair of the Earth Resources Theme of the International Geoscience program (IGCP). Prof. Nasiris specialized in applied mineralogy and petrology, and herelishes his continued involvement in teaching and research and contributes to undergraduate and postgraduate teaching in various fields of Earth Sciences. He have published more than 320 papers and books, and he built his international reputation through his research focusing on Oman and the Arabian lithosphere. $\mathrm{He}$ is a member in several editorial board of international journals in earth sciences. He received many regional and international research funding for his research as well as many international awards including the ESESCO Prize for Science and Technology 2016.

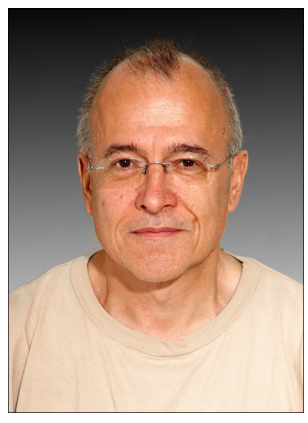

Juergen Koepke is Professor for petrology at the Leibniz University Hannover in Germany. His main interest is the understanding of the geodynamics of mid-ocean ridges, especially the magmatic processes and those metamorphic processes at the interface between igneous and hydrothermal processes. For this he focus on performing ship cruises to mid-ocean ridge systems of recent oceans, on field campaigns in the Oman ophiolite and on the experimental simulation of relevant magmatic processes related to the construction of the ocean crust especially with respect to the role of $\mathrm{aH}_{2} \mathrm{O}$ and $\mathrm{fO}_{2}$ on phase equilibria and the evolution of $\mathrm{SiO}_{2}$-rich melts within basaltic systems. He is co-PI of several IODP proposals and also of the ICDP Oman Drilling Project. 